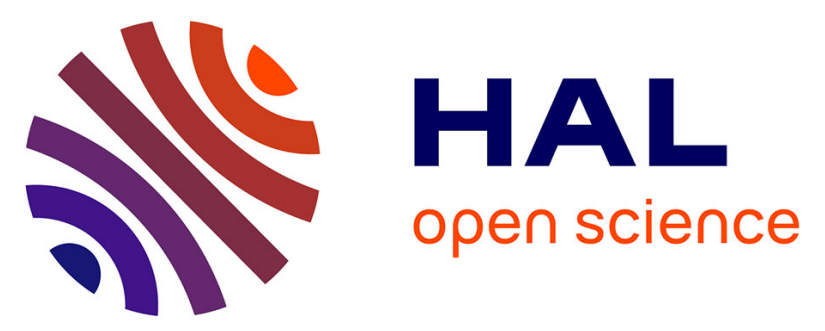

\title{
Simultaneous solvent extraction and transesterification of jatropha oil for biodiesel production, and potential application of the obtained cakes for binderless particleboard
}

Ika Amalia Kartika, Philippe Evon, Muriel Cerny, O. Suparno, D. Hermawan, Danu Ariono, Luc Rigal

\section{To cite this version:}

Ika Amalia Kartika, Philippe Evon, Muriel Cerny, O. Suparno, D. Hermawan, et al.. Simultaneous solvent extraction and transesterification of jatropha oil for biodiesel production, and potential application of the obtained cakes for binderless particleboard. Fuel, 2016, vol. 181, pp. 870-877. 10.1016/j.fuel.2016.05.038 . hal-01343159

\author{
HAL Id: hal-01343159 \\ https://hal.science/hal-01343159
}

Submitted on 7 Jul 2016

HAL is a multi-disciplinary open access archive for the deposit and dissemination of scientific research documents, whether they are published or not. The documents may come from teaching and research institutions in France or abroad, or from public or private research centers.
L'archive ouverte pluridisciplinaire $\mathbf{H A L}$, est destinée au dépôt et à la diffusion de documents scientifiques de niveau recherche, publiés ou non, émanant des établissements d'enseignement et de recherche français ou étrangers, des laboratoires publics ou privés. 


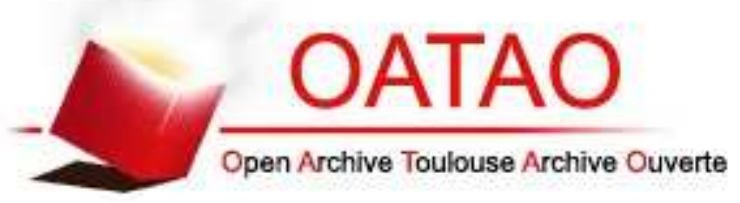

\section{Open Archive TOULOUSE Archive Ouverte (OATAO)}

OATAO is an open access repository that collects the work of Toulouse researchers and makes it freely available over the web where possible.

This is an author-deposited version published in : http://oatao.univ-toulouse.fr/ Eprints ID : 15851

To link to this article : DOI : 10.1016/j.fuel.2016.05.038

URL : http://dx.doi.org/10.1016/j.fuel.2016.05.038

To cite this version : Amalia Kartika, Ika and Evon, Philippe and Cerny, Muriel and Suparno, O. and Hermawan, D. and Ariono, Danu and Rigal, Luc Simultaneous solvent extraction and transesterification of jatropha oil for biodiesel production, and potential application of the obtained cakes for binderless particleboard. (2016) Fuel, vol. 181. pp. 870-877. ISSN 0016-2361

Any correspondence concerning this service should be sent to the repository administrator: staff-oatao@ listes-diff.inp-toulouse.fr 


\title{
Simultaneous solvent extraction and transesterification of jatropha oil for biodiesel production, and potential application of the obtained cakes for binderless particleboard
}

\author{
I. Amalia Kartika ${ }^{\mathrm{a}, *}$, P. Evon ${ }^{\mathrm{b}, \mathrm{c}}$, M. Cerny ${ }^{\mathrm{b}, \mathrm{c}}$, O. Suparno $^{\mathrm{a}}$, D. Hermawan ${ }^{\mathrm{d}}$, D. Ariono ${ }^{\mathrm{e}}$, L. Rigal ${ }^{\mathrm{b}, \mathrm{c}}$ \\ ${ }^{a}$ Department of Agroindustrial Technology, FATETA-IPB, Darmaga Campus, P.O. Box 220, Bogor 16002, Indonesia \\ ${ }^{\mathrm{b}}$ Université de Toulouse, INP, Laboratoire de Chimie Agro-industrielle, ENSIACET, 4 allée Émile Monso, BP 44362, 31030 Toulouse Cedex 4, France \\ ' INRA, Laboratoire de Chimie Agro-industrielle, 31030 Toulouse, France \\ ${ }^{\mathrm{d}}$ Department of Forest Product, FAHUTAN-IPB, Darmaga Campus, Bogor 16680, Indonesia \\ ${ }^{\mathrm{e}}$ Department of Chemical Engineering, FTI-ITB, Ganesha 10 Road, Bandung 40132, Indonesia
}

\section{H I G H L I G H T S}

- We investigate the biodiesel production directly from jatropha seeds.

- We investigate the binderless particleboard production from cakes as by-product.

- Increasing $n$-hexane and methanol to seed ratios will increase yield and quality.

- Increasing cakes moisture content will increase binderless particleboard quality.

Keywords:

Biofuel

Jatropha

Meal

Panel

Reactive extraction

\section{A B S T R A C T}

This study investigated biodiesel production from jatropha seeds in a single step, i.e. by simultaneous solvent extraction and transesterification of jatropha oil, and possibility to transform the obtained cakes into binderless particleboards. $n$-Hexane was used as extracting solvent. The best operating conditions were identified to obtain optimal biodiesel yield and quality, and optimal physical and mechanical properties for binderless particleboards. Biodiesel yield was usually influenced by operating conditions, and the influences of both $n$-hexane to seed and methanol to oil ratios were most significant. An increase in $n$-hexane to seed ratio (from 1:1 to 3:1) combined with the decrease in methanol to oil ratio (from 13.3:1 to 8.0:1) led to an improvement in biodiesel yield. The best biodiesel yield (92\% with a fatty acid methyl ester purity $>98 \%$ ) was obtained from $2: 1 n$-hexane to seed ratio, 10.6:1 methanol to oil ratio, 200-600 rpm stirring speed, $50^{\circ} \mathrm{C}$ temperature and $6 \mathrm{~h}$ reaction time. Operating conditions had no significant effect on the biodiesel quality, except the $n$-hexane to seed ratio. Moreover, cohesive particleboards were produced from the obtained cakes, proteins and fibers acting respectively as binder and reinforcing fillers. An increase in the cake moisture content significantly improved the particleboard properties. The most promising binderless particleboard was manufactured from cake B under $20 \%$ cake moisture content and $160{ }^{\circ} \mathrm{C}$ pressing temperature. Its properties were $0.87 \mathrm{~g} / \mathrm{cm}^{3}$ density, $8.4 \%$ moisture content, 7.2 MPa modulus of rupture, 10.4 GPa modulus of elasticity, 0.14 MPa internal bonding strength, $52 \%$ water absorption and 20\% thickness swelling after $24 \mathrm{~h}$ immersion in water.

\section{Introduction}

The cultivation of Jatropha curcas spread widely in Central and South America, South-East Asia, India and Africa [1]. It is a drought-resistant plant with many utilizations and great prospec-

\footnotetext{
* Corresponding author.

E-mail address: ikatk@yahoo.com (I. Amalia Kartika).
}

tive [2-6]. This plant was widely developed to reclaim land, prevent and/or control erosion, as well as an energy source for biofuel production $[7,8]$.

The seed is the highest potential of the jatropha plant due to its high oil (40-60\%) and protein (20-30\%) contents [1,8]. Furthermore, the biodiesel produced from jatropha oil is regarded as a potential substitute to diesel fuel with certain advantage, such as 
its high flash point [7]. It is thus not dangerous to stock up and handle.

The biodiesel synthesis from vegetable oils by conventional industrial technology consists of many separate steps including oil extraction from the seed by mechanical pressing and solvent extraction using $n$-hexane as extracting solvent [9-11], oil refining by degumming, neutralization, bleaching and deodorization $[12,13]$, and then alkaline transesterification of oil with monohydric alcohol $[14,15]$. A large part of the industrial biodiesel production has applied this technology. However, as the cost for vegetable oil production is very high (approximately $70 \%$ of the biodiesel production costs) [7,8,16-19], a new biodiesel production process, simple, compact, efficient, low cost and less energy consumer, is necessary to be developed.

The in situ transesterification has been applied with success for biodiesel production from various oilseeds [6,8,16-30]. The conversion of jatropha seeds into fatty acid methyl esters (FAME) by acidcatalyzed in situ transesterification has been reported by Shuit et al. [26]. A 99.8\% FAME yield was obtained under reaction conditions of $60{ }^{\circ} \mathrm{C}$ temperature, $24 \mathrm{~h}$ duration, $7.5 \mathrm{~mL} / \mathrm{g}$ methanol to seed ratio, 15 wt. $\% \mathrm{H}_{2} \mathrm{SO}_{4}$, seed particle size less than $0.355 \mathrm{~mm}$ and $n$-hexane as co-solvent [26]. In this study, the processing steps and cost for biodiesel production were successfully reduced by conducting the solvent extraction and the in situ acidic transesterification of jatropha seeds in a single step. On the other hand, the simultaneous solvent extraction with $n$-hexane as extracting solvent and in situ transesterification with $\mathrm{KOH}$ as catalyst have also been successfully carried out for the direct conversion of jatropha seeds to FAME [8]. A $87 \%$ biodiesel yield with a fatty acid methyl ester purity of $99.7 \%$ was obtained under reaction conditions of $50{ }^{\circ} \mathrm{C}$ temperature, $800 \mathrm{rpm}$ stirring speed, $5 \mathrm{~h}$ duration, $6 \mathrm{~mL} / \mathrm{g}$ methanol to seed ratio, $6.4 \mathrm{wt} . \% \mathrm{KOH}$ and seed particle size of 35 mesh. The biodiesel production from jatropha seeds by simultaneous solvent extraction and in situ transesterification increased both yield and quality of biodiesel. The constant ratio of $n$-hexane added to the seed (i.e. $1: 1$ for all experiments, expressed in $\mathrm{mL} / \mathrm{g}$ ) was used in this study. In addition, a single step for solvent extraction and alkaline transesterification of oil from jatropha seeds at pilot scale with different ratios of $n$-hexane to seed has never been reported. Thus, a comprehensive study should be conducted to examine the effect of $n$-hexane to seed ratio. Furthermore, the latter should also investigate the possibility of reducing the large reacting methanol volume (molar ratio of reacting methanol to jatropha oil of 104:1) used in the previous study [8] while maintaining a high FAME yield.

The residual oil and FAME contained in the cake after biodiesel production by the in situ transesterification of jatropha seeds is high (more than $11 \%$ ) [8]. Even though the direct utilization of the cake (i.e. for animal feed) is less favorable, the conversion of this cake into usable energy by combustion, gasification or pyrolysis is more advantageous [31,32]. In addition, due to its excellent action as reinforcing filler for a biodegradable polymer (i.e. polycaprolactone/PCL), the cake has considerable potential in biocomposite applications [33]. As a mixture of proteins and lignocellulosic fibers, the transformation of the cake into biodegradable and value-added agromaterials by thermo-pressing could also be considered [34-43]. Thus, the possibility to produce cohesive binderless particleboards from cakes obtained after in situ transesterification of jatropha seeds should be also examined.

This study was conducted to investigate biodiesel production from jatropha seeds in a single step, i.e. by simultaneous solvent extraction and transesterification of jatropha oil, at pilot scale. The influences of $n$-hexane to seed ratio, methanol to oil ratio, stirring speed, temperature and reaction time were examined to identify the optimal reaction conditions and to define best performance of biodiesel yield and quality. In addition, the influence of thermopressing conditions, i.e. pressing temperature and moisture content, on the physical and mechanical properties of binderless particleboards produced from the obtained cakes was also evaluated.

\section{Materials and methods}

\subsection{Materials}

For all trials conducted in this study, the whole jatropha seeds used were from IP2 Lampung variety, and they were supplied by the Indonesian Spices and Industrial Crops Research Institute (Sukabumi, Indonesia). At storage, the moisture content of jatropha seeds was $7.8 \pm 0.5 \%$ (French standard NF V 03-903). n-Hexane ( $>98 \%$ purity) and methanol (>98\% purity) were obtained from Brataco Chemical Ltd (Indonesia). All analysis solvents and chemicals were pure analytical grades, and they were obtained from Sigma-Aldrich, Fluka and J.T. Baker (Indonesia and France).

\subsection{Experimental procedure for biodiesel production}

For biodiesel production, the moisture content of jatropha seeds was less than $2 \%$ (French standard NF V 03-903). To obtain jatropha seeds with less than $2 \%$ moisture content, they were dried in a ventilated oven at $60-70{ }^{\circ} \mathrm{C}$ for $24-48 \mathrm{~h}$. Then, the dried seeds were milled using an electric grinder fitted with a 20 mesh size.

Milled jatropha seeds (1000 g) and methanol in which KOH had been dissolved (concentration fixed at $0.075 \mathrm{~mol} / \mathrm{L}$ ) were mixed. The methanol to oil ratio ( $\mathrm{v} / \mathrm{w}$, expressed in $\mathrm{mL} / \mathrm{g}$ ) was $8: 1-13: 1$. To increase oil miscibility in the mixture, to accelerate the reaction and to complete it in a single phase, $n$-hexane was then added (1000-3000 mL), corresponding to a $1: 1-1: 3$ seed to $n$-hexane ratio $(\mathrm{w} / \mathrm{v})$. The total solvent to seed ratio ( $\mathrm{v} / \mathrm{w}$, expressed in $\mathrm{mL} /$ g) was thus 6:1 for all the experiments conducted. Both $\mathrm{KOH}$ amount and total solvent to seed ratio were based on optimal values from the previous study [8]. The biodiesel production was conducted using a reactor with $10 \mathrm{~L}$ capacity. The latter was equipped with a reflux system, an agitator and a heater. The other operating conditions tested were the stirring speed (200-600 rpm), the temperature $\left(40-50^{\circ} \mathrm{C}\right)$ and the reaction time (4-6 h).

When the reaction has been completed, the mixture was cooled to ambient temperature. Then, it was filtered vacuum, allowing the separation between the filtrate and the cake. Methanol and $n$-hexane were recovered from the filtrate by evaporation using a rotary evaporator, and this made possible to separate the filtrate into two layers. Dark brown in color, the lower layer contained glycerol. The upper one constituted the crude biodiesel, and it was yellow in color. It contained not only the fatty acid methyl esters produced but also the unreacted glycerides (triglycerides, diglycerides and monoglycerides) like other impurities. Methanol and $n$-hexane may extract other materials than glycerides, such as fatty acids and phospholipids. After washing with water until neutrality, the crude biodiesel was then dried $\left(105^{\circ} \mathrm{C}, 1 \mathrm{~h}\right)$. Its fatty acid methyl ester, triglyceride, diglyceride, monoglyceride and fatty acid contents were then determined using gas chromatography. The washed and dried crude biodiesel was weighed, and the biodiesel yield was calculated using the same equation as that used in the previous study [8]. Each experiment was conducted twice, thus leading to an average value and a standard deviation for the biodiesel yield. The isolated cake still contained part of the fatty acid methyl esters produced during the in situ transesterification because it was not washed with methanol to take out the esters. It was dried overnight at room temperature. The influence of all operating conditions (i.e. methanol to oil ratio, $n$-hexane to seed ratio, stirring speed, temperature and reaction time) on biodiesel yield and biodiesel quality was studied through a randomized 
factorial experimental design with analysis of variance (ANOVA, F-test at $p=0.05$ ) using SAS software.

\subsection{Experimental procedure for binderless particleboard manufacture}

For binderless particleboard production, the boards were manufactured by thermo-pressing using two different cakes originating from the biodiesel production: cake A with no screening treatment, and cake B with screening treatment using a 40 mesh sieve. Their moisture contents at storage were $6.6 \pm 0.1 \%$ and $5.6 \pm 0.3 \%$, respectively (French standard NF V 03-903).

The cakes were thermo-pressed inside a forming box, using a 20 ton capacity heated hydraulic press. The forming box was needed in this case to ensure a good repeatability of the obtained particleboard dimension and a good homogeneity of the board thickness over its entire surface. However, for particleboard production on an industrial scale this procedure is uncommon. $100 \mathrm{~mm} \times 100 \mathrm{~mm}$ square prototypes with a $5 \mathrm{~mm}$ particleboard thickness and a $0.8 \mathrm{~g} / \mathrm{cm}^{3}$ targeted density were produced. The starting materials had moisture contents of $10 \%$ or $20 \%$. The cakes were hand-formed into homogeneous single-layered mats, and they were pre-pressed manually. The top and bottom surfaces of mats were then covered with aluminum plates. The cake quantity, the applied pressure and the pressing time were $40 \mathrm{~g}, 20 \mathrm{MPa}$ and $10 \mathrm{~min}$, respectively, for all the experiments conducted. At the same time, three different pressing temperatures were tested for each cake, i.e. $140{ }^{\circ} \mathrm{C}, 160^{\circ} \mathrm{C}$ and $180^{\circ} \mathrm{C}$, respectively. Each experiment was conducted twice, thus leading to an average value and a standard deviation for each physical and mechanical property determined for particleboard. Subsequently, the particleboards were equilibrated for two weeks in a climatic chamber $\left(30^{\circ} \mathrm{C}\right.$ and $70 \% \mathrm{RH}$ ) before being tested.

\subsection{Analytical methods}

The French standards NF V 03-903 and NF V 03-322 were used to determine moisture and ash contents, respectively. The French standard NF V 18-100 was used to determine protein content. The Indonesian standard SNI 01-2891-1992 was used to determine crude fiber content. The French standard NF V 03-908 was used to determine oil and $n$-hexane extracted matter content. The glyceride fraction content in oil extracted from jatropha seed and its composition were analyzed by gas chromatography. For that, the same method as those described in the previous study [8] was used.

The quality of biodiesel was analyzed after its production. It includes acid value, saponification value, iodine value and viscosity. Standards used to conduct such measurements were French standard NF T 60-204, Indonesian standard SNI 01-3555-1998, American standard AOCS-Cd 1d-92 and American standard AOAC 974:07, respectively. In addition, gas chromatography was used to determine the biodiesel fatty acid methyl ester content. For that, the same method as those described in the previous study [8] was used. A complete characterization of the optimal biodiesel produced was conducted using the Indonesian Biodiesel Standard (SNI 04-7182-2006). All determinations were carried out in duplicate.

\subsection{Binderless particleboard characterizations}

The physical (i.e. density, water absorption and thickness swelling after $24 \mathrm{~h}$ immersion in water) and mechanical properties (i.e. internal bonding strength and flexural properties) of binderless particleboards produced from the cakes were evaluated in accordance with the Japanese standard JIS A 5908-2003. A $50 \mathrm{~mm} \times 50 \mathrm{~mm} \times 5 \mathrm{~mm}$ specimen was prepared to measure moisture content and density of particleboard. Subsequently, two $75 \mathrm{~mm} \times 25 \mathrm{~mm} \times 5 \mathrm{~mm}$ specimens were prepared from each particleboard to measure its flexural properties, i.e. modulus of rupture (MOR) and modulus of elasticity (MOE). In addition, two $50 \mathrm{~mm} \times 50 \mathrm{~mm} \times 5 \mathrm{~mm}$ specimens were prepared from each particleboard to measure its internal bonding strength. These bending and internal bonding tests were both conducted using an Instron 3369 (USA) universal testing machine. For water absorption and thickness swelling measurements after soaking in distilled water at room temperature for $24 \mathrm{~h}$, two $50 \mathrm{~mm} \times 50 \mathrm{~mm} \times 5 \mathrm{~mm}$ specimens were also prepared from each particleboard. All determinations were carried out in duplicate.

\section{Results and discussion}

\subsection{Biodiesel production from jatropha seeds}

In this study, less than $2 \%$ moisture content and $37.6 \pm 1.2 \%$ oil content (expressed in relation to the wet matter content of seed) in jatropha seeds were used for all experiments. The jatropha oil was composed of $99.0 \pm 0.5 \%$ glyceride fraction, i.e. $95.8 \pm 0.2 \%$ triglycerides, $2.6 \pm 0.1 \%$ diglycerides and $0.3 \pm 0.0 \%$ monoglycerides, and it also contained $1.4 \pm 0.1 \%$ free fatty acids as reported in the previous study [8]. In alkali-catalyzed transesterification, the moisture and free fatty acid contents should be controlled as low as possible due to their negative effect on biodiesel yield. Indeed, the presence of water can lead to ester saponification and can reduce the oil dissolution in methanol due to its high polarity, the conversion of triglycerides into FAME being consequently low. On the other hand, the free fatty acid can rapidly react with alkaline catalyst to form soap. The amount of catalyst available for transesterification may thus be reduced, decreasing the biodiesel production yield.

The biodiesel processing by concurrent solvent extraction and transesterification of oil from jatropha seeds had a positive influence on both yield and quality of biodiesel. The combination of these two processes allows oil extraction to be applied to seed and then alkaline transesterification of the extracted oil with methanol as solvent and reactant. Actually the miscibility of methanol and oil was very low, so for oil extraction it was an ineffective solvent. On the other hand, the mass transfer of oil into alcohol (methanol or ethanol) can be enhanced by adding a cosolvent such as $n$-hexane into the reaction mixture $[6,25,26,28]$. Furthermore, the transesterification reaction between oil and alcohol can be intensified by this addition of co-solvent. In the case of jatropha, $n$-hexane was an efficient solvent to limit the removal of the free fatty acids and water from the seeds, as well as an effective solvent for oil extraction, due to its non-polarity $[11,25]$. In this study, the ratio of $n$-hexane added to seed was varied from $1: 1$ to $3: 1$ (volume/weight, expressed in $\mathrm{mL} / \mathrm{g}$ ) for all experiments. Increasing the ratio of $n$-hexane added to seed may have a positive effect on one-step preparation of biodiesel production from jatropha seeds. Most triglycerides are non-polar long chain hydrocarbon molecules, the use of $n$-hexane as non-polar co-solvent can thus facilitate the triglycerides extracted from seeds. Higher ratio of $n$-hexane added to seed, higher triglycerides extracted from seeds, the conversion of triglycerides into FAME being consequently high.

The experimental design of randomized factorial was carried out to comprehensively analyze the effect of $n$-hexane to seed ratio, methanol to oil ratio, stirring speed, temperature and reaction time on biodiesel yield. For this study, the total solvent (i.e. methanol plus $n$-hexane) to seed ratio was fixed constant at $6: 1$ (volume/weight, expressed in $\mathrm{mL} / \mathrm{g}$ ) but the $n$-hexane to seed ratio was varied $(1: 1-3: 1)$, meaning that the methanol to oil or 
seed ratios also varied $(8.0: 1-13.3: 1$ or $3: 1-5: 1$, respectively). The results obtained are shown in Table 1 , and generally biodiesel yield was affected by $n$-hexane to seed ratio, methanol to oil ratio, stirring speed, temperature and reaction time. But, based on the results of variance analysis (F-test at $p=0.05$ ), the influence of $n$-hexane to seed ratio and methanol to oil ratio on biodiesel yield was more significant than for the three other conditions (Table 2). For all operating conditions tested, a slight increase in biodiesel yield was observed when the $n$-hexane to seed ratio increased from $1: 1$ to $3: 1$, and the methanol to oil ratio simultaneously decreased from 13.3:1 to 8.0:1. Thus, the use of $n$-hexane as co-solvent enhanced the jatropha oil to methyl esters conversion with reduced volumes of reacting methanol.

The effect of methanol to oil ratio on the biodiesel yield was significant, as previously observed by other researchers $[6,8,17,19,22,24,25,28,30]$. For all operating conditions tested, a slight increase in biodiesel yield was observed when the methanol to oil ratio decreased from 13.3:1 to 8.0:1. However, the fatty acid methyl ester (FAME) purity of biodiesel largely decreased with this decrease in methanol to oil ratio from 13.3:1 to 8.0:1 (Table 1). In addition, the analysis of variance ( $F$-test at $p=0.05$ ) applied to actual data of FAME purity of biodiesel shows that it was significantly affected by methanol to oil ratio (Table 2). Thus, a methanol to oil ratio of only 8.0:1 was not sufficient for complete transesterification of the triglycerides released from the jatropha seeds. On the other hand, an increase in biodiesel yield was observed when the $n$-hexane to seed ratio increased from $1: 1$ to $3: 1$, and the fatty acid methyl ester purity of biodiesel decreased with this increase in $n$-hexane to seed ratio. At higher $n$-hexane to seed ratio, the triglycerides released from jatropha seeds were also higher. However, as the ratio of methanol added to oil was too low in that case, it was not sufficient for complete transesterification of those triglycerides. In this study, higher biodiesel yield with higher FAME purity was obtained when methanol to oil ratio or methanol to seed ratio were at least $10.6: 1$ or $4: 1$, respectively, and when $n$-hexane to seed ratio was at most $2: 1$ (expressed in $\mathrm{mL} / \mathrm{g}$ ). The best biodiesel processing from jatropha seeds (92\% yields with a fatty acid methyl ester purity of $>98 \%$ ) was then obtained with 200-600 rpm stirring speed, $50^{\circ} \mathrm{C}$ temperature and $6 \mathrm{~h}$ reaction time. For comparison, the best biodiesel yield reported in the previous study [8] was lower (i.e. only $87 \%$ with a fatty acid methyl ester purity of $99.7 \%$ ), and it was obtained under reaction conditions of $800 \mathrm{rpm}$ stirring speed, $50^{\circ} \mathrm{C}$ temperature, $5 \mathrm{~h}$ reaction time, $6 \mathrm{~mL} / \mathrm{g}$ methanol to seed ratio (i.e. $6: 1$ ), and $1 \mathrm{~mL} / \mathrm{g}$ $n$-hexane to seed ratio (i.e. $1: 1$ ). Thus, the best biodiesel yield of the present study was obtained under lower stirring speed (200 rpm vs $800 \mathrm{rpm}$ ) and methanol to seed ratio (4:1 vs $6: 1$ corresponding to $73: 1$ vs $104: 1$ expressed in relation to molar ratio of methanol to oil) but under higher $n$-hexane to seed ratio ( $2: 1$ vs $1: 1$ ) and reaction time ( $6 \mathrm{~h}$ vs $5 \mathrm{~h}$ ). On the other hand, compared with the molar ratio of methanol to oil and the amount of catalyst $(\mathrm{KOH})$ required for conventional transesterification of different oils $[3,14,15]$, the in situ transesterification of jatropha oil from seeds used about 12 times more methanol (73:1 M ratio of methanol to oil) and 4.7 times more $\mathrm{KOH}$ (4.7 wt.\% $\mathrm{KOH}$ based on oil weight) than the conventional method (6:1 $\mathrm{M}$ ratio of methanol to oil and $1 \mathrm{wt} . \% \mathrm{KOH}$ ). However, the excess reagents could be recovered for reuse, especially methanol.

Based on light microscope images from seeds during biodiesel production by in situ transesterification, the oil extraction and transesterification occur inside the seed, followed by product diffusion into the bulk solvent [30]. The concentration gradient of biodiesel between the inside of the seed and the bulk solvent caused the product diffusion into the solvent. The concentration gradient decreased as the amount of solvent was reduced, and the product yield was therefore low. In this study, the total solvent (i.e. methanol plus $n$-hexane) used for all experiments was constant. Thus, the concentration gradient of biodiesel between the inside of the seed and the bulk solvent was probably constant. Based on that phenomenon, the decrease in the fatty acid methyl ester purity of biodiesel produced at low methanol to oil ratio and low amount of $\mathrm{KOH}$ in methanol was probably caused

Table 1

Effect of operating conditions on process performance and crude biodiesel quality (6:1 solvent to seed ratio and $0.075 \mathrm{~mol} / \mathrm{L} \mathrm{KOH}$ in methanol).

\begin{tabular}{|c|c|c|c|c|c|c|c|c|c|c|c|}
\hline \multirow{2}{*}{$\begin{array}{l}\text { Stirring } \\
\text { speed } \\
(\mathrm{rpm})\end{array}$} & \multirow{2}{*}{$\begin{array}{l}\text { Temperature } \\
\left({ }^{\circ} \mathrm{C}\right)\end{array}$} & \multirow{2}{*}{$\begin{array}{l}\text { Reaction } \\
\text { time }(\mathrm{h})\end{array}$} & \multirow{2}{*}{$\begin{array}{l}\text { Methanol } \\
\text { to oil ratio } \\
(\mathrm{v} / \mathrm{w})\end{array}$} & \multirow{2}{*}{$\begin{array}{l}n \text {-Hexane to } \\
\text { seed ratio } \\
(\mathrm{v} / \mathrm{w})\end{array}$} & \multirow{2}{*}{$\begin{array}{l}\text { Crude } \\
\text { yield } \\
\text { (wt.\%) }\end{array}$} & \multirow{2}{*}{$\begin{array}{l}\text { Acid value } \\
(\mathrm{mg} \mathrm{KOH} / \mathrm{g})\end{array}$} & \multirow[t]{2}{*}{$\mathrm{SV}(\mathrm{mg} \mathrm{KOH} / \mathrm{g})$} & \multirow{2}{*}{$\begin{array}{l}\text { Viscosity at } \\
40^{\circ} \mathrm{C} \\
\left(10^{-6} \mathrm{~m}^{2} / \mathrm{s}\right)\end{array}$} & \multirow{2}{*}{$\begin{array}{l}\text { Ash } \\
\text { content } \\
\text { (wt.\%) }\end{array}$} & \multicolumn{2}{|c|}{ Composition (wt.\%) } \\
\hline & & & & & & & & & & FAME & $\begin{array}{l}\text { Impurities } \\
\text { (DAG, MAG, } \\
\text { TAG, FA) }\end{array}$ \\
\hline 200 & 40 & 4 & $8.0: 1$ & $3: 1$ & $91 \pm 0$ & $0.24 \pm 0.01$ & $192 \pm 2$ & $4.3 \pm 0.8$ & 0.0 & $97.7 \pm 0.1$ & 2.3 \\
\hline 200 & 40 & 4 & $10.6: 1$ & $2: 1$ & $90 \pm 0$ & $0.20 \pm 0.05$ & $187 \pm 3$ & $3.5 \pm 0.0$ & 0.0 & $99.2 \pm 0.2$ & 0.8 \\
\hline 200 & 40 & 4 & $13.3: 1$ & $1: 1$ & $87 \pm 2$ & $0.26 \pm 0.13$ & $185 \pm 4$ & $3.4 \pm 0.0$ & 0.0 & $99.2 \pm 0.5$ & 0.8 \\
\hline 200 & 40 & 6 & $8.0: 1$ & $3: 1$ & $93 \pm 3$ & $0.20 \pm 0.05$ & $186 \pm 4$ & $5.4 \pm 2.5$ & 0.0 & $96.0 \pm 0.1$ & 4.0 \\
\hline 200 & 40 & 6 & $10.6: 1$ & $2: 1$ & $90 \pm 1$ & $0.20 \pm 0.05$ & $193 \pm 6$ & $3.5 \pm 0.0$ & 0.0 & $99.0 \pm 0.1$ & 1.0 \\
\hline 200 & 40 & 6 & $13.3: 1$ & $1: 1$ & $90 \pm 3$ & $0.20 \pm 0.05$ & $191 \pm 4$ & $3.5 \pm 0.1$ & 0.0 & $95.1 \pm 0.5$ & 4.9 \\
\hline 200 & 50 & 4 & $8.0: 1$ & $3: 1$ & $88 \pm 3$ & $0.26 \pm 0.13$ & $187 \pm 5$ & $3.6 \pm 0.0$ & 0.0 & $98.3 \pm 0.6$ & 1.7 \\
\hline 200 & 50 & 4 & $10.6: 1$ & $2: 1$ & $88 \pm 1$ & $0.20 \pm 0.05$ & $185 \pm 6$ & $3.5 \pm 0.0$ & 0.0 & $98.8 \pm 0.5$ & 1.2 \\
\hline 200 & 50 & 4 & $13.3: 1$ & $1: 1$ & $87 \pm 1$ & $0.20 \pm 0.05$ & $191 \pm 1$ & $3.5 \pm 0.0$ & 0.0 & $99.0 \pm 0.4$ & 1.0 \\
\hline 200 & 50 & 6 & $8.0: 1$ & $3: 1$ & $88 \pm 1$ & $0.20 \pm 0.05$ & $183 \pm 2$ & $4.1 \pm 0.5$ & 0.0 & $84.7 \pm 2.5$ & 15.3 \\
\hline 200 & 50 & 6 & $10.6: 1$ & $2: 1$ & $92 \pm 0$ & $0.26 \pm 0.13$ & $190 \pm 4$ & $3.5 \pm 0.1$ & 0.0 & $98.0 \pm 2.3$ & 2.0 \\
\hline 200 & 50 & 6 & $13.3: 1$ & $1: 1$ & $89 \pm 6$ & $0.20 \pm 0.05$ & $189 \pm 0$ & $3.6 \pm 0.0$ & 0.0 & $98.9 \pm 0.7$ & 1.1 \\
\hline 600 & 40 & 4 & $8.0: 1$ & $3: 1$ & $91 \pm 0$ & $0.20 \pm 0.05$ & $187 \pm 1$ & $3.7 \pm 0.3$ & 0.0 & $96.5 \pm 3.1$ & 3.5 \\
\hline 600 & 40 & 4 & $10.6: 1$ & $2: 1$ & $90 \pm 1$ & $0.20 \pm 0.05$ & $188 \pm 3$ & $3.5 \pm 0.0$ & 0.01 & $98.4 \pm 0.5$ & 1.6 \\
\hline 600 & 40 & 4 & $13.3: 1$ & $1: 1$ & $87 \pm 2$ & $0.20 \pm 0.05$ & $184 \pm 4$ & $3.5 \pm 0.0$ & 0.02 & $98.6 \pm 0.1$ & 1.4 \\
\hline 600 & 40 & 6 & $8.0: 1$ & $3: 1$ & $94 \pm 2$ & $0.20 \pm 0.05$ & $183 \pm 1$ & $4.2 \pm 1.0$ & 0.0 & $86.1 \pm 4.5$ & 13.9 \\
\hline 600 & 40 & 6 & $10.6: 1$ & $2: 1$ & $90 \pm 1$ & $0.20 \pm 0.05$ & $186 \pm 1$ & $3.5 \pm 0.0$ & 0.0 & $98.9 \pm 0.1$ & 1.1 \\
\hline 600 & 40 & 6 & $13.3: 1$ & $1: 1$ & $89 \pm 3$ & $0.26 \pm 0.13$ & $186 \pm 3$ & $3.5 \pm 0.1$ & 0.02 & $98.4 \pm 1.5$ & 1.6 \\
\hline 600 & 50 & 4 & $8.0: 1$ & $3: 1$ & $91 \pm 3$ & $0.20 \pm 0.05$ & $192 \pm 2$ & $4.0 \pm 0.1$ & 0.0 & $96.4 \pm 0.8$ & 3.6 \\
\hline 600 & 50 & 4 & $10.6: 1$ & $2: 1$ & $91 \pm 2$ & $0.20 \pm 0.05$ & $184 \pm 0$ & $3.5 \pm 0.0$ & 0.0 & $99.1 \pm 0.3$ & 0.9 \\
\hline 600 & 50 & 4 & $13.3: 1$ & $1: 1$ & $88 \pm 1$ & $0.20 \pm 0.05$ & $187 \pm 7$ & $3.5 \pm 0.0$ & 0.01 & $97.5 \pm 0.3$ & 2.5 \\
\hline 600 & 50 & 6 & $8.0: 1$ & $3: 1$ & $89 \pm 4$ & $0.20 \pm 0.05$ & $186 \pm 6$ & $4.1 \pm 0.1$ & 0.0 & $91.8 \pm 2.5$ & 8.2 \\
\hline 600 & 50 & 6 & $10.6: 1$ & $2: 1$ & $92 \pm 1$ & $0.20 \pm 0.05$ & $184 \pm 1$ & $3.5 \pm 0.0$ & 0.0 & $99.1 \pm 0.1$ & 0.9 \\
\hline 600 & 50 & 6 & $13.3: 1$ & $1: 1$ & $88 \pm 3$ & $0.20 \pm 0.05$ & $183 \pm 3$ & $3.5 \pm 0.0$ & 0.0 & $98.4 \pm 1.8$ & 1.6 \\
\hline
\end{tabular}

SV, saponification value; FAME, fatty acid methyl esters; MAG, monoglycerides; DAG, diglycerides; TAG, triglycerides; FA, free fatty acids. 
Table 2

$F$ value obtained from analysis of variance (ANOVA) for crude biodiesel yield and quality.

\begin{tabular}{|c|c|c|c|c|c|c|c|}
\hline Source of variation & $\begin{array}{l}F \text { value for crude } \\
\text { yield }\end{array}$ & $\begin{array}{l}F \text { value for acid } \\
\text { value }\end{array}$ & $\begin{array}{l}F \text { value } \\
\text { for SV }\end{array}$ & $\begin{array}{l}F \text { value for ash } \\
\text { content }\end{array}$ & $\begin{array}{l}F \text { value for } \\
\text { viscosity }\end{array}$ & $\begin{array}{l}F \text { value for FAME } \\
\text { composition }\end{array}$ & $\begin{array}{l}F \text { value at } \\
p=0.05\end{array}$ \\
\hline Reaction time $(A)$ & 3.07 & 0.29 & 0.62 & 0.20 & 1.86 & $41.90(\mathrm{~S})$ & 4.26 \\
\hline Stirring speed $(B)$ & 1.21 & 0.00 & 0.54 & 3.36 & 3.11 & 0.74 & 4.26 \\
\hline $\begin{array}{l}n \text {-Hexane to seed ratio and methanol } \\
\text { to oil ratio }(C)\end{array}$ & $6.82(S)$ & 0.29 & 0.03 & 0.20 & $3.65(S)$ & $58.13(S)$ & 3.40 \\
\hline Temperature $(D)$ & 1.20 & 0.07 & 0.02 & 2.07 & 0.02 & 0.31 & 4.26 \\
\hline Interaction of $A B$ & 0.43 & 0.50 & 1.44 & 0.06 & 1.67 & 1.48 & 4.26 \\
\hline Interaction of $A C$ & 0.23 & 0.21 & 0.44 & 2.07 & 1.29 & $28.49(\mathrm{~S})$ & 3.40 \\
\hline Interaction of $A D$ & 0.47 & 0.07 & 0.07 & 0.06 & 0.16 & 0.16 & 4.26 \\
\hline Interaction of $B C$ & 0.29 & 0.00 & 0.02 & 1.82 & 1.59 & 1.50 & 3.40 \\
\hline Interaction of $B D$ & 0.60 & 0.29 & 0.04 & 0.00 & 0.31 & $6.81(S)$ & 4.26 \\
\hline Interaction of $C D$ & 2.79 & 1.14 & 0.21 & 1.82 & 0.33 & 1.58 & 3.40 \\
\hline Interaction of $A B C$ & 0.05 & 0.29 & 1.23 & 0.00 & 1.15 & 0.61 & 3.40 \\
\hline Interaction of $A B D$ & 1.22 & 0.21 & 0.31 & 0.93 & 0.11 & $7.83(S)$ & 4.26 \\
\hline Interaction of $A C D$ & 2.16 & 0.07 & 0.21 & 0.26 & 0.38 & 3.33 & 3.40 \\
\hline Interaction of $B C D$ & 0.03 & 0.07 & 0.64 & 0.93 & 0.08 & $12.34(\mathrm{~S})$ & 3.40 \\
\hline Interaction of $A B C D$ & 0.08 & 0.50 & 0.49 & 0.26 & 0.29 & $13.31(\mathrm{~S})$ & 3.40 \\
\hline
\end{tabular}

S, significant.

by the insufficient conversion of triglycerides into esters inside the seed.

The reaction rate of jatropha oil conversion into biodiesel was significantly influenced by the reaction temperature due to the large dependency of intrinsic rate constants on temperature $[8,25]$. An enhancement of reactant solubility and reaction rate, as well as a reduction of oil viscosity and reaction time, can be attained at a higher reaction temperature [15,30]. Furthermore, the latter favors reaction with its higher activation energy produced [44]. In this study, the results showed that when reaction temperature increased from $40{ }^{\circ} \mathrm{C}$ to $50^{\circ} \mathrm{C}$, biodiesel yield was relatively stable. These results are in agreement with the previous studies $[17,19,28]$, where the conversion of triglycerides into biodiesel can be conducted at both low and high temperature. Here, the efficient solvent extraction and transesterification for biodiesel production, performed at low temperature, is thus favorable to reduce the economic cost of the process.

In alkali-catalyzed in situ transesterification, longer reaction time generally has a positive effect on triglyceride conversion $[15,17,22,24,25]$. Nevertheless, within the $4-6 \mathrm{~h}$ reaction time investigated in this study, increasing this parameter did not systematically increase the biodiesel yield, as previously reported by Amalia Kartika et al. [8], Abo El-Enin et al. [19] and Ozgul-Yucel and Turkay [21]. Instead, biodiesel yield was relatively stable with an increase of the reaction time from $4 \mathrm{~h}$ to $6 \mathrm{~h}$, meaning that the system had already attained the equilibrium composition after only $4 \mathrm{~h}$. Biodiesel yield is normally maximum as reaction time is optimum (e.g. at a value less than 90 min for transesterification of isolated and refined vegetable oils), and for any further reaction time increase it is then relatively stable [15]. Moreover, the biodiesel yield will reduce due to reverse transesterification reactions if reaction time is too long. A previous study indicated that the in situ transesterification reaction from jatropha seeds [28] with alkali as catalyst was extremely rapid, requiring only $20 \mathrm{~min}$ for complete conversion.

In this study, stirring speed did not influence the biodiesel yield as previously reported by Amalia Kartika et al. [8]. Indeed, the latter was relatively stable with an augmentation of the stirring speed from $200 \mathrm{rpm}$ to $600 \mathrm{rpm}$, meaning that the lowest stirring speed of $200 \mathrm{rpm}$ was adequate to efficiently blend the reactants before the single phase system was established. The latter is formed when methyl esters are produced as they take action as a co-solvent for the reactants. Furthermore, the mixing effect is not important as the establishment of the single phase system is achieved. This phenomenon was also observed by Kasim and Harvey [28] where the
$200 \mathrm{rpm}$ stirring speed was sufficient to uniformly distribute the seeds and the reactant.

The quality of biodiesel obtained in this study was acceptable for all reaction conditions tested (Table 1). The biodiesel was high in fatty acid methyl ester content (i.e. more than 95\% purity), especially that produced from $1: 1$ or $2: 1 n$-hexane to seed ratio. In addition, it had low acid value, low viscosity and low ash content, i.e. less than $0.3 \mathrm{mg}$ of $\mathrm{KOH} / \mathrm{g}$ of biodiesel, less than $5.4 \cdot 10^{-6} \mathrm{~m}^{2} / \mathrm{s}$, and $0-0.02 \mathrm{wt} . \%$, respectively. On the other hand, it had more than $183 \mathrm{mg}$ of $\mathrm{KOH} / \mathrm{g}$ saponification value.

The results of variance analysis ( $F$-test at $p=0.05$ ) showed that the influence of reaction conditions on biodiesel quality, in particular viscosity and FAME purity, was significant, mainly the ones of $n$-hexane to seed ratio and methanol to oil ratio (Table 2). This phenomenon was exactly similar as previously observed on biodiesel yield. The effect of $n$-hexane to seed ratio and methanol to oil ratio was thus significant on both biodiesel yield and biodiesel purity. Furthermore, the reaction conditions had no effect on ash content, acid and saponification values of biodiesel. Indeed, they were relatively stable as $n$-hexane to seed ratio, methanol to oil ratio, stirring speed, temperature and reaction time increased.

In addition, the simultaneous solvent extraction and in situ transesterification of jatropha seeds tested under optimal reaction conditions (2:1 $n$-hexane to seed ratio, 10.6:1 methanol to oil ratio, $200 \mathrm{rpm}$ stirring speed, $50^{\circ} \mathrm{C}$ temperature, and $6 \mathrm{~h}$ reaction time) produced a biodiesel with specifications conforming to ASTM D 6751 and EN 14214 standards, just as the SNI 04-7182-2006 Indonesian Biodiesel Standard (Table 3). These specifications were thus favorable for its use as automotive diesel.

\subsection{Binderless particleboard manufacture from the obtained cakes}

After biodiesel production, the obtained cakes revealed quite high residual $n$-hexane extracted matter contents (i.e. residual oil plus fatty acid methyl esters). This could be a disadvantage for their direct utilization. However, these cakes would be transformable into renewable and biodegradable particleboards $[34,36-40,42,43]$, thus satisfying one of the principles of biorefinery, i.e. the overall valorization of biomass with no waste generation. Two different cakes have been tested: cake A with no screening treatment, and cake B with screening treatment using a 40 mesh sieve. Their $n$-hexane extracted matter contents were $7.6 \pm 0.1 \%$ and $4.8 \pm 0.2 \%$, respectively. Both cakes were mixtures of proteins ( $18.1 \pm 1.0 \%$ for cake A and $34.7 \pm 0.6 \%$ for cake B) and lignocellulosic fibers $(41.0 \pm 0.9 \%$ for cake $A$ and $19.8 \pm 0.8 \%$ for 
Table 3

Quality of jatropha crude biodiesel produced under optimal reaction conditions (6:1 solvent to seed ratio, $200 \mathrm{rpm}$ stirring speed, $50{ }^{\circ} \mathrm{C}$ temperature, and $6 \mathrm{~h}$ reaction time).

\begin{tabular}{|c|c|c|c|c|c|}
\hline Parameter & Unit & $\begin{array}{l}\text { Jatropha } \\
\text { biodiesel }\end{array}$ & $\begin{array}{l}\text { Biodiesel standard of SNI 04- } \\
7182-2006\end{array}$ & $\begin{array}{l}\text { Biodiesel standard of ASTM D } \\
6751[45]\end{array}$ & $\begin{array}{l}\text { Biodiesel standard of EN } 14214 \\
\text { [45] }\end{array}$ \\
\hline Density at $40^{\circ} \mathrm{C}$ & $\mathrm{g} / \mathrm{cm}^{3}$ & 0.878 & $0.850-0.890$ & $0.875-0.900\left(15^{\circ} \mathrm{C}\right)$ & $0.860-0.900\left(15^{\circ} \mathrm{C}\right)$ \\
\hline Viscosity at $40^{\circ} \mathrm{C}$ & $10^{-6} \mathrm{~m}^{2} / \mathrm{s}$ & 3.5 & $2.3-6.0$ & $1.9-6.0$ & $3.5-5.0$ \\
\hline Flash point & ${ }^{\circ} \mathrm{C}$ & 182 & $100 \mathrm{~min}$ & $130 \mathrm{~min}$ & $120 \mathrm{~min}$ \\
\hline Pour point & ${ }^{\circ} \mathrm{C}$ & 0 & - & $(-15)-10$ & $0 \max$ \\
\hline Cloud point & ${ }^{\circ} \mathrm{C}$ & 12 & $18 \max$ & - & - \\
\hline Acid value & $\mathrm{mg} \mathrm{KOH} / \mathrm{g}$ & 0.26 & $0.8 \max$ & $0.5 \max$ & $0.5 \max$ \\
\hline Cetane number & - & 51.8 & $51 \mathrm{~min}$ & $47 \mathrm{~min}$ & $51 \mathrm{~min}$ \\
\hline $\begin{array}{l}\text { Water and sediment } \\
\text { content }\end{array}$ & $\%$, wt & Trace $(<0.05)$ & $0.05 \max$ & $0.05 \max$ & $0.05 \max$ \\
\hline Sulfated ash content & $\%, \mathrm{wt}$ & 0.001 & $0.02 \max$ & $0.02 \max$ & $0.02 \max (\%, \mathrm{~mol} / \mathrm{mol})$ \\
\hline Total glycerine content & $\%$, wt & 0.17 & $0.24 \max$ & $0.24 \max$ & $0.25 \mathrm{max}(\%, \mathrm{~mol} / \mathrm{mol})$ \\
\hline Free glycerine content & $\%$, wt & 0.013 & $0.02 \max$ & $0.02 \max$ & $0.02 \max (\%, \mathrm{~mol} / \mathrm{mol})$ \\
\hline Iodine number & $\begin{array}{l}\text { g iodine/ } \\
100 \mathrm{~g}\end{array}$ & 94.7 & $115 \max$ & - & $120 \max$ \\
\hline HHV & $\mathrm{MJ} / \mathrm{kg}$ & 37.7 & - & - & $35 \mathrm{~min}$ \\
\hline Composition: & $\%$ wt & & & & \\
\hline Fatty acid methyl esters & & 98.0 & - & - & $96.5 \mathrm{~min}(\%, \mathrm{~mol} / \mathrm{mol})$ \\
\hline Monoglycerides (MAG) & & 0.1 & - & - & $0.8 \max (\%, \mathrm{~mol} / \mathrm{mol})$ \\
\hline Diglycerides (DAG) & & 0 & - & - & $0.2 \max (\%, \mathrm{~mol} / \mathrm{mol})$ \\
\hline Triglycerides (TAG) & & 0 & - & - & $0.2 \max (\%, \mathrm{~mol} / \mathrm{mol})$ \\
\hline
\end{tabular}

cake B). They could thus be considered as natural composites. Proteins could act as an internal binder inside boards, improving the material cohesion. In parallel, the entanglement of fibers could also contribute to mechanically reinforce the particleboard [36-40]. Both cakes also contained ash $(6.1 \pm 0.2 \%$ for cake $\mathrm{A}$ and $11.4 \pm 0.1 \%$ for cake B), and other components, i.e. mainly carbohydrates $(20.6 \%$ for cake A and $23.6 \%$ for cake B). Their moisture content was $10 \%$ or $20 \%$. Moisture can promote the adhesion of proteins and fibers during the hot press processing [34]. In addition, due to the plasticizing effect of water on jatropha proteins [39], the presence of moisture in these cakes may facilitate the movement of polypeptide chains (i.e. proteins), thus possibly leading to better interactions with other polymers.

For the particleboard manufacture, the raw materials used in this study thus contain significant amounts of proteins (18-35\%), lignocellulosic fibers (20-41\%) and carbohydrates (21-24\%). These components may serve as internal binders when they are thermopressed using high pressure in the presence of moisture, as previously observed by Hidayat et al. [42], and their binding capacity may be based upon several reactions and interactions, such as protein denaturation and plasticization, hydrogen bonding between the polar carbohydrate components (cellulose, hemicelluloses and starch) and proteins or lignins, and lignin auto-crosslinking reactions.

In particular, using proteins as adhesive to manufacture particleboards has been already carried out successfully $[34,46]$. The strength of such adhesive depends on the protein ability to disperse in water and on the interactions of its apolar and polar groups with fibers [47]. Thus, the presence of proteins, fibers and moisture in cakes A and B should strongly contribute to the selfbonding of particleboards, providing a good internal cohesion.

Cake quantity, applied pressure and pressing time were $40 \mathrm{~g}$, $20 \mathrm{MPa}$ and $10 \mathrm{~min}$, respectively, for all the experiments conducted. The pressing temperature used for cake A was $180^{\circ} \mathrm{C}$, and three different pressing temperatures were tested for cake $\mathrm{B}$, i.e. $140{ }^{\circ} \mathrm{C}, 160^{\circ} \mathrm{C}$ and $180^{\circ} \mathrm{C}$. The eight particleboards produced using these operating conditions (Table 4) were all cohesive boards, proteins and fibers acting respectively as natural binder and reinforcing fillers. After their conditioning in climatic chamber $\left(30^{\circ} \mathrm{C}\right.$ and $70 \% \mathrm{RH}$ ), density and moisture content of binderless particleboards increased for each cake with the increase in the cake moisture content (from 10\% to $20 \%$ ). In addition, this led also to a decrease in both water absorption and thickness swelling after
$24 \mathrm{~h}$ immersion in water. This reduction in the water sensitivity of particleboard could be correlated to its increasing density, a lowering in the internal porosity thus restricting the diffusion of water inside the material during soaking. It may be attributed to better distribution of the proteins on the fiber surface, the presence of more moisture in the cake improving the ability of proteins to flow and so the wetting of the fibers.

On the other hand, the pressing temperature did not significantly affect the physical properties of binderless particleboards. When the pressing temperature increased from $140^{\circ} \mathrm{C}$ to $180^{\circ} \mathrm{C}$, the density of equilibrated particleboards remained stable at $0.8 \mathrm{~g} / \mathrm{cm}^{3}$ and $0.9 \mathrm{~g} / \mathrm{cm}^{3}$, respectively, for $10 \%$ and $20 \%$ cake moisture content. Similarly, the equilibrated particleboards revealed also stable moisture content at $6.4-6.6 \%$ and $8.1-8.5 \%$, respectively. Concerning water absorption and thickness swelling, they remained also relatively stable with the increase in the pressing temperature. However, a slight increase in these two values was observed between $160^{\circ} \mathrm{C}$ and $180^{\circ} \mathrm{C}$ pressing temperatures.

Comparing particleboards thermo-pressed at $180^{\circ} \mathrm{C}$ from cakes $\mathrm{A}$ and $\mathrm{B}$, the decrease in the $n$-hexane extracted matter content in the cake led to a slight increase in both board density and especially internal bonding strength. This was probably due to higher protein content in cake B, the poorest one in lipids. And, this confirmed the binding ability of proteins inside binderless particleboards. Moreover, for all particleboards produced, their flexural properties were clearly correlated with their internal bonding strength. Indeed, the more the internal bonding strength, the higher the modulus of rupture and the higher the modulus of elasticity (Table 4).

The cake moisture content largely affected the mechanical properties of equilibrated particleboards. When moisture content of the cake increased from $10 \%$ to $20 \%$, the internal bonding strength increased significantly for all pressing temperatures tested: at least $+43 \%$ (Table 4 ). Logically, this contributed also to a significant increase in the modules of rupture and elasticity: at least $+50 \%$ and $+52 \%$, respectively. Water can induce a wide range of physical and chemical changes in the presence of heat, in particular the denaturation and the plasticization of proteins [42]. This had a positive effect in the binding properties of proteins, thus contributing to the increases in the board's internal bonding strength and thus in its bending properties.

Indeed, the polar functions in proteins (amides) are capable of linking water molecules through hydrogen interactions. Water 
Table 4

Characteristics of binderless particleboards from cakes obtained after in situ transesterification of jatropha seeds (20 MPa applied pressure and 10 min pressing time).

\begin{tabular}{|c|c|c|c|c|c|c|c|c|c|}
\hline Cake type & $\begin{array}{l}\text { Cake moisture } \\
\text { content (wt.\%) }\end{array}$ & $\begin{array}{l}\text { Pressing } \\
\text { temperature }\left({ }^{\circ} \mathrm{C}\right)\end{array}$ & $\begin{array}{l}\text { Density } \\
\left(\mathrm{g} / \mathrm{cm}^{3}\right)\end{array}$ & $\begin{array}{l}\text { Moisture } \\
\text { content } \\
\text { (wt.\%) }\end{array}$ & $\begin{array}{l}\text { Water } \\
\text { absorption } \\
(\%, 24 \mathrm{~h})\end{array}$ & $\begin{array}{l}\text { Thickness } \\
\text { swelling } \\
(\%, 24 \mathrm{~h})\end{array}$ & $\begin{array}{l}\text { Modulus of } \\
\text { rupture (MPa) }\end{array}$ & $\begin{array}{l}\text { Modulus of } \\
\text { elasticity (GPa) }\end{array}$ & $\begin{array}{l}\text { Internal } \\
\text { bonding (MPa) }\end{array}$ \\
\hline A & 10 & 180 & $0.80 \pm 0.03$ & $6.4 \pm 0.65$ & $85.1 \pm 0.19$ & $30.9 \pm 0.70$ & $2.3 \pm 0.02$ & $5.2 \pm 0.83$ & $0.045 \pm 0.003$ \\
\hline A & 20 & 180 & $0.86 \pm 0.01$ & $8.1 \pm 0.35$ & $55.6 \pm 0.64$ & $26.1 \pm 0.66$ & $5.7 \pm 0.51$ & $7.9 \pm 0.35$ & $0.079 \pm 0.003$ \\
\hline B & 10 & 180 & $0.83 \pm 0.03$ & $6.4 \pm 0.18$ & $83.8 \pm 0.26$ & $29.8 \pm 0.73$ & $3.7 \pm 0.02$ & $5.1 \pm 0.03$ & $0.061 \pm 0.004$ \\
\hline B & 20 & 180 & $0.88 \pm 0.01$ & $8.5 \pm 0.18$ & $56.0 \pm 0.39$ & $26.7 \pm 0.94$ & $6.3 \pm 0.04$ & $8.2 \pm 0.58$ & $0.087 \pm 0.003$ \\
\hline B & 10 & 160 & $0.82 \pm 0.01$ & $6.6 \pm 0.41$ & $78.6 \pm 0.17$ & $22.7 \pm 0.38$ & $4.8 \pm 0.18$ & $5.9 \pm 0.18$ & $0.068 \pm 0.002$ \\
\hline B & 20 & 160 & $0.87 \pm 0.01$ & $8.4 \pm 0.16$ & $51.9 \pm 0.42$ & $20.3 \pm 0.18$ & $7.2 \pm 0.10$ & $10.4 \pm 0.36$ & $0.139 \pm 0.003$ \\
\hline B & 10 & 140 & $0.81 \pm 0.03$ & $6.6 \pm 0.30$ & $79.3 \pm 1.21$ & $23.4 \pm 0.59$ & $4.2 \pm 0.11$ & $5.6 \pm 0.12$ & $0.066 \pm 0.001$ \\
\hline B & 20 & 140 & $0.88 \pm 0.01$ & $8.4 \pm 0.14$ & $51.1 \pm 0.59$ & $20.4 \pm 0.74$ & $7.1 \pm 0.26$ & $9.7 \pm 0.57$ & $0.127 \pm 0.005$ \\
\hline
\end{tabular}

contributes to separate the proteins, thus facilitating their movement and improving also their thermoplastic properties [39]. Therefore, the thermal and rheological properties of proteins depend largely on the amount of water, their glass transition temperature depending on their hydration.

For all operating conditions, temperature plus shear (i.e. the pressure) applied resulted in the glass transition of proteins. Consequently, proteins were always in a rubbery state during thermo-pressing. This led to the wetting of the fibers and to the manufacture of cohesive boards. However, at $20 \%$ moisture content, proteins in their rubbery state were less viscous than with only $10 \%$ moisture content, thus leading to an improvement in the fiber wetting and also in the binding effect of proteins inside boards. This was illustrated by the increase in the internal bonding strength (Table 4). This logically resulted in the production of materials much more resistant to bending than those made at only $10 \%$ moisture content, and this phenomenon was observed for all pressing temperatures tested, as well as for both cakes A and B. In addition, for the $180^{\circ} \mathrm{C}$ pressing temperature, the internal bonding strength and so the modules of rupture and elasticity of particleboards produced from cake $B$ were higher than those of particleboards produced from cake A. As previously mentioned, such difference in the mechanical properties was probably due to higher protein content in cake B, thus leading to more bound particleboards. Lastly, comparing particleboards produced from cake $\mathrm{B}$, the optimal pressing temperature was $160^{\circ} \mathrm{C}$ for the internal bonding strength, and consequently also for the flexural properties. A pressing temperature of only $140^{\circ} \mathrm{C}$ resulted in higher viscosity of proteins in their rubbery state, thus probably altering their ability to wet correctly the surface of the fibers during thermopressing and consequently reducing their binding capacity. On the contrary, a $180^{\circ} \mathrm{C}$ pressing temperature was probably too high, leading perhaps to the partial thermal degradation of some organic compounds inside the cakes, especially the proteins.

In conclusion, the best physical and mechanical properties of binderless particleboard were obtained from cake B with $20 \%$ moisture content and under $160^{\circ} \mathrm{C}$ pressing temperature. When it was equilibrated in climatic chamber, this optimal particleboard revealed subsequently characteristics: $0.87 \mathrm{~g} / \mathrm{cm}^{3}$ density, $8.4 \%$ moisture content, 51.9\% water absorption, 20.3\% thickness swelling, 7.2 MPa modulus of rupture, 10.4 GPa modulus of elasticity and $0.14 \mathrm{MPa}$ internal bonding strength. For comparison, a previous study consisted in producing binderless particleboards by thermo-pressing using a press cake originating from the mechanical pressing of oil from jatropha seeds using a twin-screw extruder [39]. And, the best mechanical properties of binderless particleboard were in that case obtained under pressing temperature of $200{ }^{\circ} \mathrm{C}$, that is $1.28 \mathrm{~g} / \mathrm{cm}^{3}$ density, $5.9 \%$ moisture content, $7.2 \mathrm{MPa}$ modulus of rupture and $2.2 \mathrm{GPa}$ modulus of elasticity. In this present study, a comparable modulus of rupture and a much higher modulus of elasticity were obtained under lower pressing temperature $\left(160^{\circ} \mathrm{C}\right.$ instead of $\left.200^{\circ} \mathrm{C}\right)$.
The optimal particleboard of this study complied with the Japanese standard JIS A 5908-2003 type 8 (i.e. base particleboards and decorative particleboards) for density, moisture content and modulus of elasticity (recommendations of $0.4-0.9 \mathrm{~g} / \mathrm{cm}^{3}, 5-13 \%$ and $2 \mathrm{GPa}$, respectively) but not exactly for modulus of rupture, internal bonding strength and thickness swelling (recommendations of $8.0 \mathrm{MPa}, 0.15 \mathrm{MPa}$ and $12 \%$ after $24 \mathrm{~h}$ immersion in water, respectively). Firstly, it is reasonable to assume that an additional amount of proteins in the cake would lead to a better board's cohesion, thus resulting in an improvement in both mechanical characteristics (i.e. internal bonding strength and therefore modulus of rupture). Secondly, an additional process such as preheating, chemical, or steam treatment would probably reduce the board's sensitivity to water [48-50]. Moreover, if used in humid climates, the resistance to microbial mold of this particleboard should be studied in the future. Lastly, this optimal particleboard was environmentally friendly due to the absence of formaldehyde emissions during its use. Indeed, unlike most commercial particleboards, the binder used here to produce a cohesive material was not an emitting formaldehyde resin (e.g. urea or phenolic resin) but the protein-based resin naturally contained inside the cake. Compared to the current commercial particleboards, this constitutes undoubtedly an interesting novelty for this study.

\section{Conclusion}

The simultaneous solvent extraction of jatropha oil from seeds and in situ transesterification of the oil were successfully carried out in this study. This new technology for biodiesel processing from jatropha seeds is promising, allowing $n$-hexane extraction to be applied to oilseeds and transesterification to the extracted oil. Under the optimal reaction conditions, biodiesel yield reached $92 \%$ and the fatty acid methyl ester purity was more than $98 \%$. From such conditions, the biodiesel quality conformed to the Indonesian biodiesel standard. On the other hand, the cake originating from this process could be transformed into cohesive particleboards with promising physical and mechanical properties for the optimal board $\left(0.87 \mathrm{~g} / \mathrm{cm}^{3}\right.$ density, $8.4 \%$ moisture content, 7.2 MPa modulus of rupture, $10.4 \mathrm{GPa}$ modulus of elasticity, $0.14 \mathrm{MPa}$ internal bonding strength, 52\% water absorption and $20 \%$ thickness swelling). Such renewable and biodegradable boards would be usable as base particleboards or decorative particleboards. However, initially, it will be necessary to slightly improve their flexural and internal bonding strengths, and their thickness swelling to fully meet the recommendations of the Japanese standard for particleboards, type 8 .

\section{Acknowledgment}

The authors would like to acknowledge the DP2M DIKTI for financial support (Grant of National Strategy with contract no. 13 4/SP2H/PL/Dit.Litabmas/V/2013). 


\section{References}

[1] Gubiz GM, Mittelbach M, Trabi M. Exploitation of the tropical oil seed plant Jatropha curcas L. Bioresour Technol 1999;67:73-82.

[2] Openshaw K. A review of Jatropha curcas: an oil plant of unfulfilled promise. Biomass Bioenergy 2000;19:1-15.

[3] Achten WMJ, Verchot L, Franken YJ, Mathijs E, Singh VP, Aerts R, et al. Jatropha biodiesel production and use. Biomass Bioenergy 2008;32:1063-84.

[4] Becker K, Makkar HPS. Jatropha curcas: a biodiesel source for tomorrow's oil and biodiesel. Lipid Technol. 2008;20:104-7.

[5] Kumar A, Sharma S. An evaluation of multipurpose oil seed crop for industrial uses (Jatropha curcas L.): a review. Ind Crops Prod 2008;28:1-10.

[6] Lian S, Li H, Tang J, Tong D, Hu C. Integration of extraction and transesterification of lipid from jatropha seeds for the production of biodiesel. Appl Energy 2012;98:540-7.

[7] Silitonga AS, Atabani AE, Mahlia TMI, Masjuki HH, Badruddin IA, Mekhilef S. A review on prospect of Jatropha curcas for biodiesel in Indonesia. Renew Sustain Energy Rev 2011;15:3733-56.

[8] Amalia Kartika I, Yani M, Ariono D, Evon P, Rigal L. Biodiesel production from jatropha seeds: solvent extraction and in situ transesterification in a single step. Fuel 2013;106:111-7.

[9] Karaj S, Müller J. Optimizing mechanical oil extraction of Jatropha curcas L. seeds with respect to press capacity, oil recovery and energy efficiency. Ind Crops Prod 2011;34:1010-6.

[10] Tambunan AH, Situmorang JP, Silip JJ, Joelianingsih A, Araki T. Yield and physicochemical properties of mechanically extracted crude Jatropha curcas L. oil. Biomass Bioenergy 2012;43:12-7.

[11] Ofori-Boateng C, Teong LK, JitKang L. Comparative exergy analyses of Jatropha curcas oil extraction methods: solvent and mechanical extraction processes. Energy Convers Manage 2012;55:164-71.

[12] Karleskind A. Oils and fats manual. Paris: Lavoisier TEC \& DOC; 1996.

[13] Mba OI, Dumont MJ, Ngadi M. Palm oil: processing, characterization and utilization in the food industry - a review. Food Biosci 2015;10:26-41.

[14] Ma F, Hanna MA. Biodiesel production: a review. Bioresour Technol 1999;70:1-15.

[15] Leung DYC, Wu X, Leung MKH. A review on biodiesel production using catalyzed transesterification. Appl Energy 2010;87:1083-95.

[16] Harrington KJ, d'Arcy-Evans C. Transesterification in situ of sunflower seed oil. Ind Eng Chem Prod Res Develop 1985;24:314-8.

[17] Haas MJ, Scott KM, Marmer WN, Foglia TA. In situ alkaline transesterification: an effective method for the production of fatty acid esters from vegetable oils. J Am Oil Chem Soc 2004:81:83-9.

[18] Haas MJ, McAloon AJ, Yee WC, Foglia TA. A process model to estimate biodiesel production costs. Bioresour Technol 2006;97:671-8.

[19] Abo El-Enin SA, Attia KN, El-Ibiari NN, El-Diwani GI, El-Khatib KM. In-situ transesterification of rapeseed and cost indicators for biodiesel production. Renew Sustain Energy Rev 2013;18:471-7.

[20] Siler-Marinkovic S, Tomasevic A. Transesterification of sunflower oil in situ. Fuel 1998;77:1389-91.

[21] Ozgul-Yucel S, Turkay S. Variable affecting the yields of methyl esters derived from in situ esterification of rice bran oil. J Am Oil Chem Soc 2002;79:611-4.

[22] Georgogianni KG, Kontominas MG, Pomonis PJ, Avlonitis D, Gergis V. Conventional and in situ transesterification of sunflower seed oil for the production of biodiesel. Fuel Process Technol 2008;89:503-9.

[23] Ozgul-Yucel S, Turkay S. FA monoalkylester from rice bran oil by in situ transesterification. J Am Oil Chem Soc 2003;81:81-4.

[24] Qian J, Wang F, Liu S, Yun Z. In situ alkaline transesterification of cottonseed oil for production of biodiesel and nontoxic cottonseed meal. Bioresour Technol 2008;99:9009-12.

[25] Qian J, Shi H, Yun Z. Preparation of biodiesel from Jatropha curcas L. oil produced by two-phase solvent extraction. Bioresour Technol 2010;101:7025-31.

[26] Shuit SH, Lee KT, Kamaruddin AH, Yusup S. Reactive extraction and in situ esterification of Jatropha curcas L. seeds for the production of biodiesel. Fuel 2010;89:527-30.
[27] Hincapié G, Mondragón F, López D. Conventional and in situ transesterification of castor seed oil for biodiesel production. Fuel 2011;90:1618-23.

[28] Kasim FH, Harvey AP. Influence of various parameters on reactive extraction of Jatropha curcas L. for biodiesel production. Chem Eng J 2011;171:1373-8.

[29] Surya Abadi Ginting M, Tazli Azizan M, Yusup Suzana. Alkaline in situ ethanolysis of Jatropha curcas. Fuel 2012;93:82-5.

[30] Zakaria R, Harvey AP. Direct production of biodiesel from rapeseed by reactive extraction/in situ transesterification. Fuel Process Technol 2012;102:53-60.

[31] Yorgun S, Şensöz S, Koçkar ÖM. Flash pyrolysis of sunflower oil cake for production of liquid fuels. J Anal Appl Pyrol 2001;60:1-12.

[32] Gerçel HF. The production and evaluation of bio-oils from the pyrolysis of sunflower-oil cake. Biomass Bioenergy 2002;23:307-14.

[33] Diebel W, Reddy MM, Misra M, Mohanty A. Material property characterization of co-products from biofuel industries: potential uses in value added biocomposites. Biomass Bioenergy 2012;37:88-96.

[34] Li X, Li Y, Zhong Z, Wang D, Ratto JA, Sheng K, et al. Mechanical and water soaking properties of medium density fiberboard with wood fiber and soybean protein adhesive. Bioresour Technol 2009;100:3556-62.

[35] Evon P, Vandenbossche V, Pontalier PY, Rigal L. Thermo-mechanical behaviour of the raffinate resulting from the aqueous extraction of sunflower whole plant in twin-screw extruder: manufacturing of biodegradable agromaterials by thermo-pressing. Adv Mater Res 2010;112:63-72.

[36] Evon P, Vandenbossche V, Pontalier PY, Rigal L. The twin-screw extrusion technology, an original and powerful solution for the biorefinery of sunflower whole plant. Oléagineux, Corps Gras Lipides 2010;17:404-17.

[37] Evon P, Vandenbossche V, Rigal L. Manufacturing of renewable and biodegradable fiberboards from cake generated during biorefinery of sunflower whole plant in twin-screw extruder: influence of thermo-pressing conditions. Polym Degrad Stab 2012;97:1940-7.

[38] Evon P, Vandenbossche V. Pontalier PY, Rigal L. New thermal insulation fiberboards from cake generated during biorefinery of sunflower whole plant in a twin-screw extruder. Ind Crops Prod 2014;52:354-62.

[39] Evon P, Kartika IA, Rigal L. New renewable and biodegradable particleboards from jatropha press cakes. J Renew Mater 2014;2:52-65.

[40] Evon P, Vinet J, Labonne L, Rigal L. Influence of thermo-pressing conditions on the mechanical properties of biodegradable fiberboards made from a deoiled sunflower cake. Ind Crops Prod 2015;65:117-26.

[41] Lestari D, Mulder WJ, Sanders JPM. Jatropha seed protein functional properties for technical applications. Biochem Eng J 2011;53:297-304.

[42] Hidayat H, Keijsers ERP, Prijanto U, van Dam JEG, Heeres HJ. Preparation and properties of binderless boards from Jatropha curcas L. seed cake. Ind Crops Prod 2014;52:245-54.

[43] Kurniati M, Fahma F, Amalia Kartika I, Sunarti TC, Syamsu K, Hermawan D, et al. Binderless particleboard from castor seed cake: effect of pressing temperature on physical and mechanical properties. Asian J Agricult Res 2015;9:180-8.

[44] Noureddini H, Zhu D. Kinetic of transesterification of soybean oil. J Am Oil Chem Soc 1997;74:1457-63.

[45] Knothe G. Analyzing biodiesel: Standards and other methods. J Am Oil Chem Soc 2006;83:823-33.

[46] Mo X, Cheng E, Wang D, Sun S. Physical properties of medium-density wheat straw particleboard using different adhesives. Ind Crops Prod 2003;18:47-53.

[47] Kumar R, Choudhary V, Mishra S, Varma IK, Mattiason B. Adhesives and plastics based on soy protein products. Ind Crops Prod 2002;16:155-72.

[48] Halvarsson S, Edlund H, Norgren M. Manufacture of non-resin wheat straw fiberboards. Ind Crops Prod 2009;29:437-45.

[49] Saadaoui N, Rouilly A, Fares K, Rigal L. Characterization of date palm lignocellulosic by-products and self-bonded composite materials obtained thereof. Mater Des 2013;50:302-8.

[50] Widyorini R, Xu J, Umemura K, Kawai S. Manufacture and properties of binderless particleboard from bagasse: I. Effect of raw material type, storage methods, and manufacturing process. J Wood Sci 2005;51:648-54. 